\title{
補強板座屈を考慮した航空機複合材翼の最適設計*
}

\author{
加 藤 洋 子*1, 亀 山 正 樹*2 \\ 胡寧*1, 福 永久 雄 ${ }^{* 2}$
}

\section{Optimum Design of Composite Wing Considering Stiffened Panel Buckling}

\author{
Yoko KATO, Masaki KAMEYAMA, \\ Ning HU and Hisao FUKUNAGA*3 \\ ${ }^{* 3}$ Department of Aeronautics and Space Engineering, Tohoku University, \\ 01 Aramaki-Aza-Aoba, Aoba-ku, Sendai-shi, Miyagi, 980-8579 Japan
}

\begin{abstract}
The present paper treats an optimum design of CFRP stiffened panels under compressive and shear loads. Buckling analysis of stiffened panels is performed by approximate buckling formula on global and local buckling, which is based on the classical lamination theory. First in the present paper, the validity of approximate buckling formula is studied by comparing with the finite element analysis based on the Mindlin plate theory. Next, this approximate analysis technique is applied to a minimum weight design of wing box structures considering stiffened panel buckling. The optimum dimensions of stiffeners and laminate configurations are obtained by using nonlinear optimization technique. The validity of the present optimization approach is examined through the numerical results.
\end{abstract}

Key Words : Optimum Design, Composite Material, Stiffened Panel, Buckling, Approximation

\section{1. 粕言}

複合材料は金属材料に比べて軽量かつ高い比強度・ 比剛性を有することから，航空宇宙機の主要構造材料 として利用されている. しかし，一般に複合材構造物 では軽量化を目的とした構造要素の薄肉化が図られる ため, 構造の岡性低下に伴い，弾性不安定状態である 座屈を生じやすくなる. 特に航空機翼構造のように曲 げとねじりを受ける構造では，翼構造の外板に圧縮力 とせん断力が生じ座屈を起こす可能性があるため, 外 板には剛性を高くし座屈荷重を大きくするためにブレ 一ド型・J 型・Y 型・ハット型等の種々の断面形状を 有する補強パネル(1)が用いられる. 従って, 複合材翼 構造の設計において, 複合材補強パネルの座屈特性を 十分に把握しておく必要があり,これまでに VIPASA ${ }^{(2)}$, BUCLAPS2 $2^{(3)}$ に代表される多くの解析プログラムが開 発されているほか，圧縮強度試験結果との比較による 数值解析法の有効性の検討も行われている(4).

* 原稿受付 2003 年 6 月 18 日.

*1 東北大学大学院工学研究科(- 980-8579 仙台市青葉区荒巻 字青葉 01).

*2 正員, 東北大学大学院工学研究科.

E-mail : fukunaga@ssl.mech.tohoku.ac.jp
また，補強パネルを対象とした座屈特性最適化に関 しては，例えば，非線形計画法に基づく最適設計プロ

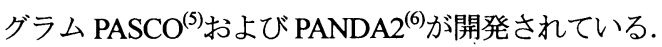
さらに, 外板がハット型補強板である箱型翼構造の最 小重量設計に対して多段階最適化法を適用した例(ク), 補強パネルの形状寸法を設計変数とした最小重量設計 に対して遺伝的アルゴリズム (GA)を適用した例(8)(9)に ついても示されている.

以上に示すように, 補強パネルの座屈解析および座 屈特性最適化に関して数多くの研究がなされている. しかし，翼構造全体を直接的に最適化する場合，ある いは最適化において GA 等の構造解析を多く必要とす る最適化手法を適用する場合には，有限要素法による 詳細な座屈解析を適用すると解析回数が膨大となり計 算コストが増大するため, できるだけ効率的な座屈解 析およびその最適化が必要となる. これまで, 全体構 造を多くの部分構造に分割し, 段階を分けて最適化を 行う多段階最適化法 ${ }^{(7)}$ や応答曲面法(9)等を適用するこ とにより解析回数の減少を図ることが検討されている.

本研究では, 複合材補強パネルの座屈解析に対し, 古典積層理論に基づく座屈近似式の有効性を検討し, 近似式を用いて翼構造の最適設計を行うことを目的と 
する，本論文においては，まず，座屈近似計算と有限 要素解析を比較することにより, 座屈近似式の有効性 を検討する. 次に, 座屈近似式を用いて複合材補強パ ネル, および補強板座屈を考虑した箱型翼構造の簡易 な最適設計を行い, 有限要素解析との比較によりその 妥当性を検討する.

\section{2. 補強パネルの座届特性}

$2 \cdot 1$ 古典積層理論に基つく近似式 図 1 に示す ような，スキン部分・補強材部分がともに CFRP 対称 積層板からなるブレード型補強パネルについて考える. 図 1(a)は補強パネルの全体図, 図1(b)は補強材 1 つ分 を取り出した詳細図である.ここで， $a$ は補強パネル の長さ, $b$ は幅とし, $N$ は補強材の個数, $d_{s}$ は補強材 1 個あたりのスキンの幅, $h$ は補強材の高さである. $N_{x}$ は $x$ 軸方向の荷重, $N_{y}$ は $y$ 軸方向の荷重, $N_{x y}$ はせん断 荷重とし, それぞれ単位長さ当たりの合力である.ま た, CFRPの材料定数を表 1 に示す.

補強パネルの全体座屈荷重は, 補強パネルを等価平 板に近似することにより求める. 近似された平板の面 外剛性は次式で表される(10).

$$
\begin{aligned}
& D_{11}=\left(D_{11}\right)_{s k i n}+\frac{E_{s t} I_{s t}}{d_{s}} \\
& D_{12}=\left(D_{12}\right)_{s k i n} \\
& D_{22}=\left(D_{22}\right)_{s k i n} \\
& D_{66}=\left(D_{66}\right)_{s k i n}+\frac{G_{s t} J_{s t}}{2 d_{s}}
\end{aligned}
$$

ここで, $D_{\mathrm{ij}}(\mathrm{i}, \mathrm{j}=1,2,6)$ は平板に近似された補強パネルの 面外剛性であり, $\left(D_{\mathrm{ij}}\right)_{s k i n}(\mathrm{i}, \mathrm{j}=1,2,6)$ は補強パネルのスキ ン部分の中立軸周りの面外剛性である. $E_{s t}, G_{s t}$ は補強 材部分のヤング率, およびせん断弾性係数であり， $I_{s t}$ は中立軸に対する補強材の断面 2 次モーメント， $J_{s t}$ は 補強材の断面 2 次極モーメントである. ただし, 今回 のように, 補強パネルが開断面であるときは, 補強材 がねじりに与える影響は小さいので $J_{s t}$ は無視する. ま た, 直交異方性板であると仮定して $D_{16}=D_{26}=0$ とした. このように近似された平板に対して古典積層理論に基 づく座屈解析を行う。

古典積層理論に基づく直交異方性平板の圧縮座屈に 関する基礎式は次式で与えられる。

$$
\begin{aligned}
D_{11} w_{, x x x} & +2\left(D_{12}+2 D_{66}\right) w_{, x x y}+D_{22} w_{, y y y y} \\
& +\left[N_{x} w_{, x x}+2 N_{x y} w_{x y}+N_{y} w_{, y y}\right]=0
\end{aligned}
$$

ここで, $w(x, y)$ は変位, $D_{\mathrm{ij}}(\mathrm{i}, \mathrm{j}=1,2,6)$ は面外剛性である.

$N_{x}\left(=k_{x} P\right), N_{y}\left(=k_{y} P\right)$ は軸圧縮合力, $N_{x y}\left(=k_{x y} P\right)$ はせん断

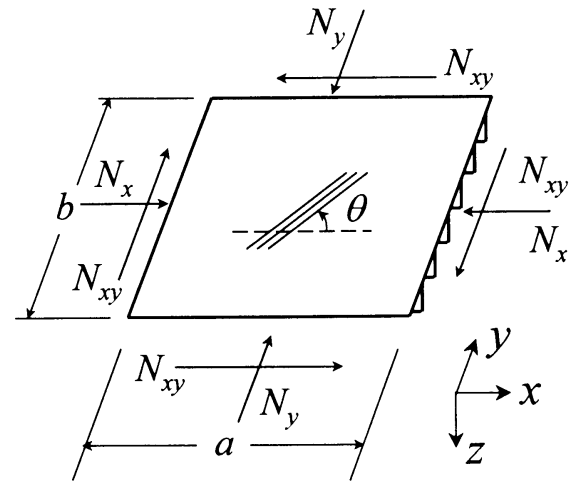

(a) Stiffened panel

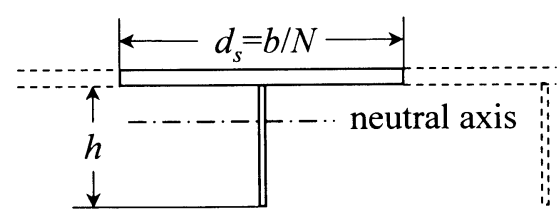

(b) Typical section

Fig.1 Stiffened panel with blade sections

Table 1 Material properties of CFRP

\begin{tabular}{ccccc}
\hline$E_{L}[\mathrm{GPa}]$ & $E_{T}[\mathrm{GPa}]$ & $G_{L T}[\mathrm{GPa}]$ & $v_{L}$ \\
\hline 131 & 13.0 & \multicolumn{2}{c}{6.41} & 0.38 \\
\hline$\varepsilon_{L c r}$ & $\varepsilon_{L c r}$ & $\varepsilon_{\text {Icr }}$ & $\varepsilon_{T c r}$ & $\gamma_{L T c r}$ \\
\hline 0.012 & 0.0090 & 0.0060 & 0.020 & 0.028 \\
\hline
\end{tabular}

合力を示し(ただし, 荷重比 $k_{x}, k_{y}, k_{x y}$ は $\max \left(k_{x}, k_{y}, k_{x y}\right)=1$ と規準化する)，図1(a)に示す方向を正とする.

境界条件は周辺単純支持の場合を考え，式(3)の変位 関数を用いる(11).

$$
w(x, y)=\sum_{m=1}^{M} \sum_{n=1}^{N} A_{m n} \sin \frac{m \pi x}{a} \sin \frac{n \pi y}{b}
$$

式(3)を式(2)に代入し Galerkin 法を適用することにより, 式(4)の固有值問題に帰着する.

$$
[K]\{\phi\}=\mu[M]\{\phi\}
$$

この固有值問題を解いて得られた最小固有値 $\mu_{\text {min }}=P_{c r}^{\text {global }}$ が全体座屈荷重を与え, 対応する固有モ一 ドが全体座屈モードとなる．ここで，作用している荷 重を $P$ とすると, 次式で示される $\lambda_{\text {global }}$ が 1 以下のとき に全体座屈が生じる.

$$
\lambda_{\text {global }}=\frac{P_{c r}^{\text {global }}}{P}
$$


補強パネルの座屈を考える場合, 全体座屈に加えて 補強材座屈と補強材間座屈(スキン座屈)の 2 種類の局 所座屈を考慮する必要がある. 補強材座屈とは補強材 部分の局所座屈現象であり，スキン座屈とは補強材と 補強材の間のスキン部分が局所座屈する現象である. これらの局所座屈荷重は以下のように求める.

まず，スキン部分と補強材部分の分担荷重を算出す る. いま, 補強材に垂直方向の荷重 $N_{y}$, およびせん断 荷重 $N_{x y}$ はすべてスキン部分が受け持つものと仮定す る. 一方, 補強材方向の圧縮荷重 $N_{x}$ は, スキン部分と 補強材部分のひずみが同じになる割合で分配して受け 持つものと仮定する. スキン部分の受け持つ割合を $r_{\text {skin }}$, 補強材部分の受け持つ割合を $r_{s t}$ とすると，それぞれに 作用する圧縮荷重 $\left(N_{x}\right)_{s k i n},\left(N_{x}\right)_{s t}$ は式(6)のように表され る.

$$
\begin{aligned}
& \left(N_{x}\right)_{s k i n}=r_{s k i n} N_{x} \\
& \left(N_{x}\right)_{s t}=r_{s t} N_{x}
\end{aligned}
$$

ここで,

$$
\begin{aligned}
& r_{s k i n}=\frac{1}{1+\frac{E_{s t} A_{s t}}{E_{s k i n} A_{s k i n}}} \\
& r_{s t}=\left(1-r_{s k i n}\right) \frac{d_{s}}{h}
\end{aligned}
$$

であり， $E_{s k n}, E_{s t}$ はそれぞれスキンおよび補強材のヤ ング率, $A_{s k i n}, A_{s t}$ は $x$ 軸に垂直な断面でのスキンおよ び補強材の断面積である.

スキン座屈荷重については, 補強材間の幅 $d_{s}$, 長さ $a$ の周辺単純支持の平板に圧縮荷重 $\left(N_{x}\right)_{s k i n}, N_{y}$ とせん断 荷重 $N_{x y}$ が作用するものと考える。この荷重を $\max \left(k_{x}^{\text {skin }}, k_{y}^{\text {skin }}, k_{x y}{ }^{\text {skin }}\right)=1$ のように規準化した荷重比を 用い, $\left(N_{x}\right)_{s k i n}=k_{x}^{s k i n} p^{s k i n}, N_{y}=k_{y}^{s k i n} p^{s k i n}, \quad N_{x y}=k_{x y}{ }^{s k i n} p^{s k i n}$ と表 し，全体座屈荷重と同様に式(3)の変位関数を用いて Galerkin 法を適用すると, 最小固有值 $\mu_{\text {min }}=P_{c r}^{\text {skin }}$ がスキ ン座屈荷重を与える.ここで, 全体座屈のときと同様 に次式で示す $\lambda_{\text {skin }}$ を導入する. $\lambda_{\text {skin }}$ が 1 以下のときにス キン座屈が生じる.

$$
\lambda_{s k i n}=\frac{P_{c r}^{s k i n}}{p^{s k i n}}
$$

補強材座屈については, 幅 $h$, 長さ $a$ の補強材に対 し，スキン部分と接している辺，および荷重の作用す る辺が単純支持, 補強材の下辺が自由端であるものと 考え, 座屈荷重を式(9)で計算する.

$$
\left(N_{x}\right)_{c r}^{s t}=\frac{2 \pi^{2}}{h^{2}}\left[\frac{6}{\pi^{2}}\left(D_{66}\right)_{s t}+\frac{1}{2}\left(D_{11}\right)_{s t}\left(\frac{h}{a}\right)^{2}\right]
$$

ここで, $\left(D_{\mathrm{ij}}\right)_{s t}(\mathrm{i}, \mathrm{j}=1,2,6)$ は補強材部分の面外剛性である. また, 式(10)に示す $\lambda_{s t}$ を導入すると, 圧縮荷重 $\left(N_{x}\right)_{s t}$ が 作用するとき, $\lambda_{s t}$ が 1 以下のときに補強材座屈が生じ る.

$$
\lambda_{s t}=\frac{\left(N_{x}\right)_{c r}^{s t}}{\left(N_{x}\right)_{s t}}
$$

$2 \cdot 2$ 近似式と有限要素解析との比較 図 1 に示 す複合材補強パネルについて, 荷重比 $k_{x}: k_{x y}\left(k_{y}=0\right)$ を変 化させたときの座屈荷重を古典積層理論に基づく近似 式，および Mindlin の板理論に基づく有限要素解析 ${ }^{(12)}$ より求め, Stroud らによる有限要素解析の結果 ${ }^{(13)}$ と比 較する. なお，スキンおよび補強材の積層構成はそれ ぞれ $[ \pm 45 / \mp 45 / 0 / 90]_{s},[ \pm 45 / \mp 45 / 0]_{s}$ とする. また， 補強材の個数 $N$ は 6 とし, 補強パネルの各寸法は, $a=b=0.762 \mathrm{~m}, h=3.43 \times 10^{-2} \mathrm{~m}, d_{s}=0.127 \mathrm{~m}, t_{0}^{s k i n}=2.79 \times 10^{-4} \mathrm{~m}$, $t_{ \pm 45}{ }^{s k i n}=1.12 \times 10^{-3} \mathrm{~m}, \quad t_{90}{ }^{s k i n}=2.51 \times 10^{-3} \mathrm{~m}, \quad t_{0}{ }^{s t}=5.59 \times 10^{-4} \mathrm{~m}$, $t_{ \pm 45}{ }^{s t}=1.12 \times 10^{-3} \mathrm{~m}$ とする. ここで, $t$ は各絨維角の層厚を 足し合わせたものを表しており, 上の添字は skin, st がそれぞれスキン部分と補強材を，下の添字は繊維角 を表している. FEM 解析要素には 8 節点アイソパラメ トリック平面要素を用い, 補強材と平行な方向に 24 分割, 垂直方向に 18 分割, 補強材の高さ方向に 3 分割 し，全部で 756 要素とした.

$N_{x}$ と $N_{x y}$ の組み合わせ荷重条件での座屈荷重の值を 図2に示す.ここでは, 荷重比 $k_{x}: k_{x y}$ が 0:1, 0.2:1, 0.5:1, 1:1, 1:0.5, 1:0 の場合の座屈荷重値を示している. この図よ り, 本研究で用いた古典積層理論に基づく近似式によ って, Stroud らの FEM 解析解と非常に近い結果が得ら れ,この近似式がブレード型補強パネルの座屈解析に 有効であることが確認できる. また, Mindlin の板理論 に基づく FEM 解析ではせん断荷重の割合が大きくな るほど Stroud らの計算値に比べ座屈荷重が小さくなっ ている.

$2 \cdot 3$ 補強板寸法が座届モ一ドに与える影㜝 2. 1 節で述べたように補強パネルには 3 種類の座屈モー ドが存在し, どの座屈モードが実際に現れるかは補強 板の形状寸法に関係している，そこで, 補強パネルの スキン厚を変化させたときの各座屈荷重を計算し, 座 屈モ一ドの変化と補強板寸法の関係を検討する.また, Mindlin の板理論に基づく FEM 解析による結果との比 較を行い, 近似式によって座屈モードの変化が正しく 求められているかを検討する.ここでは，図 1 に示す 


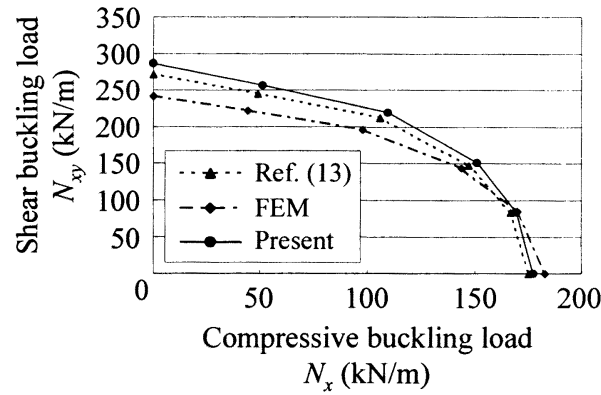

Fig.2 Approximate buckling load of stiffened panel

補強パネルに対して一軸圧縮の場合を考える.

補強パネルの他の寸法を固定したままスキン厚のみ を変化させたときの座屈荷重を図 3 に示寸.このとき, 補強パネルの寸法は, $a=b=0.762 \mathrm{~m}, h=3.00 \times 10^{-2} \mathrm{~m}$, $d_{s}=0.127 \mathrm{~m}, t_{0}^{s t}=1.20 \times 10^{-3} \mathrm{~m}, t_{445}{ }^{s t}=2.40 \times 10^{-3} \mathrm{~m}$ とした. スキ ン部分の各層の層厚の比を一定 $\left(t_{0}^{s k i n}: t_{ \pm 45}{ }^{s k i n}: t_{90}{ }^{s k i n}\right.$ =1:4:9）としたまま厚さを変化させた場合について, 近似式より得られる全体座屈荷重 $P_{c r}{ }^{\text {global }}$, 補強材座屈 荷重 $\left(N_{x}\right)_{c r}{ }^{s t} r_{s t}$, スキン座屈荷重 $P_{c r}{ }^{s k i n} / r_{s k i n}$, および FEM 解析より得られた座屈荷重の值を示している.ここで,

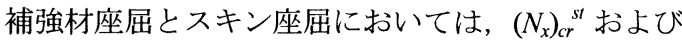
$P_{c r}{ }^{s k i n}$ は圧縮荷重を補強材とスキンに分配した荷重で あるので，全体に与える荷重に変換するため，それぞ れの座屈荷重を $r_{s t}, r_{s k i n}$ で割っている. これら 3 つの座 屈モードのうち最小の荷重が害際の座屈荷重となる. 図 3 より，スキン厚の増加に伴いスキン座屈 $\rightarrow$ 全体座 屈 補強材座屈の順に座屈モードが変化することがわ かる.これは，スキン厚が薄い場合には補強材間のス キン座屈を生じ, 逆にスキン厚が厚くなると全体座屈 を生じ，さらにスキン厚が増加することにより補強材 座屈が生じやすくなるためである. なお，スキン厚が 増加したときに補強材座屈荷重が増加するのは, $\left(N_{x}\right)_{c r}{ }^{s t}$ は変化しない一方 $r_{s t}$ が減少し, 補強材の受け持つ荷重 が少なくなるためである. また, FEM 解析と近似式に よる座屈荷重は, すべてのスキン厚に対して良く一致 していることから，本研究で用いた近似式が局所座屈 にも有効であることがわかる.

\section{3. 補強パネルの最適設計}

$3 \cdot 1$ 最暗化問題の定式化 図 1 に示すブレード 型補強パネルを対象に, $N_{x}$ と $N_{x y}$ の組み合わせ荷重条 件において全体座屈と局所座屈を考慮した複合材補強 パネルの最小重量設計を行う．スキンおよび補強材の 積層構成はそれぞれ $[ \pm 45 / \mp 45 / 0 / 90]_{s}$ ， $[ \pm 45 / \mp 45 / 0]_{s}$ とし，スキン部分・補強材部分それぞ

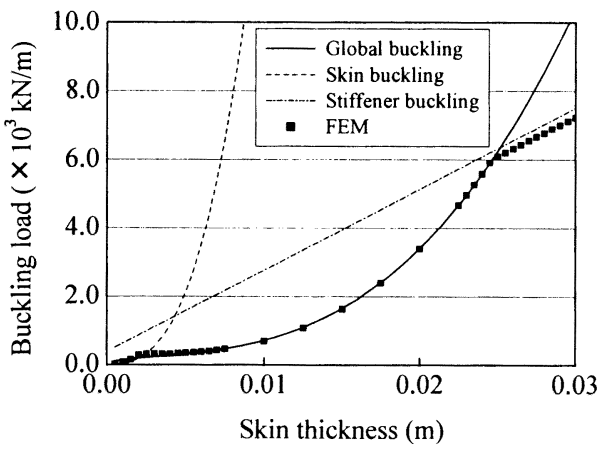

Fig.3 Buckling load of stiffened panel

れの層厚と, 補強材の高さを設計変数とし, 全体座屈 および補強材座屈, スキン座屈の 2 種類の局所座屈を 制約条件とする. この最適化問題を次式のように定式 化する.

$$
\begin{array}{cl}
\text { minimize } & W=a\left(\left(t_{0}^{\text {skin }}+t_{ \pm 45}^{s k i n}+t_{90}^{s k i n}\right) b\right. \\
& \left.+\left(t_{0}^{s t}+t_{ \pm 45}^{s t}\right) N h\right) \\
\text { subject to } & g_{\text {global }}=1-\lambda_{\text {global }} \leq 0 \\
& g_{\text {skin }}=1-\lambda_{\text {skin }} \leq 0 \\
& g_{\text {sliffrer }}=1-\lambda_{s t} \leq 0 \\
& t_{i}^{L} \leq t_{i} \leq t_{i}^{U}, \quad h^{L} \leq h \leq h^{U}
\end{array}
$$

design variables: $t_{0}^{s k i n}, t_{ \pm 45}{ }^{s k i n}, t_{90}{ }^{s k i n}, t_{0}^{s t}, t_{ \pm 45}{ }^{s t}, h$

ここで, $\lambda_{\text {global }}, \lambda_{\text {skam }}, \lambda_{s t}$ は式(5), (8), (10)により定義した值 であり, 古典積層理論に基づく近似式から求める. ま た, $t^{L}, t^{U}, h^{L}, h^{U}$ はそれぞれ層厚と補強材高さの下限值 と上限值であり, すべての要素で $t=1.00 \times 10^{-6} \mathrm{~m}$, $t^{U}=0.100 \mathrm{~m}, h^{L}=1.00 \times 10^{-2} \mathrm{~m}, h^{U}=1.00 \mathrm{~m}$ を用いる. 本研

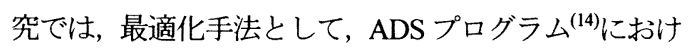
る許容方向法 (1 次元探索は黄金分割法) を適用した.

\section{$3 \cdot 2$ 計算䊅果およひ考察}

3.2.1 補強材の個数の影需 初めに, ブレード型 補強パネルの補強材の個数と最適化後の重量の関係を 検討した. 対象とする補強パネルの寸法は $a=1.75 \mathrm{~m}$, $b=3.50 \mathrm{~m}$ でアスペクト比 $a / b=0.5$ とし, 荷重条件は荷重 比が $k_{x}: k_{x y}=1: 0\left(N_{x}=2000 \mathrm{kN} / \mathrm{m}, N_{y}=N_{x y}=0\right)$ の一軸圧縮と した。また, 各設計変数の初期值として, $t_{0}^{s k i n}=t_{ \pm 45}{ }^{s k i n}=t_{90}{ }^{s k i n}=t_{0}{ }^{s t}=t_{ \pm 45}{ }^{s t}=1.00 \times 10^{-3} \mathrm{~m}, h=3.00 \times 10^{-2} \mathrm{~m}$ を用 い, 補強材の個数 $N$ を 1 30に変化させ最適化計算を 行った.

最適計算結果を図 4 に示寸. 図 4(a)は補強材の個数 と最適化後の補強パネルの重量の関係を示しており, 図中縦軸は式(11)における目的関数の収束值 $W$ である. 図 4(a)より, 最適化後のパネル重量は補強材の個数の 増加に伴いほぼ単調に減少しているものの, 補強材が 


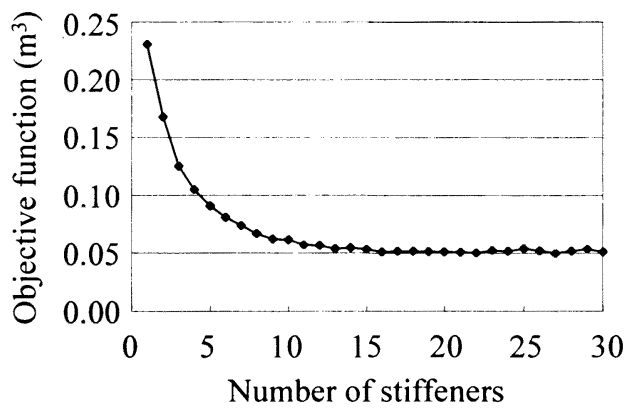

(a) Objective function

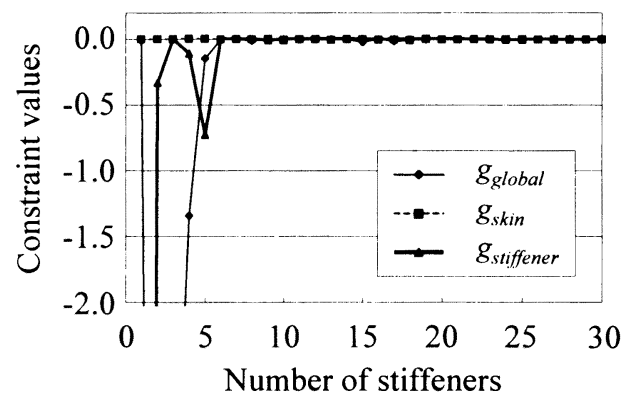

(b) Buckling mode

Fig.4 Optimum results for stiffened panel

$\left(a / b=0.5, k_{x}: k_{x y}=1: 0\right)$

ある個数に達すると，その後は補強材個数を増加させ てもパネル重量はほとんど変化していないことがわか る. なお，補強パネルの製造上の観点からは，補強パ ネルを構成する補強材の個数はできるだけ少ないこと が望ましいことから，この寸法の補強パネルにおいて 補強材個数は 15 個程度あれば十分であることがわか る. また, 図 4(b)は, 補強材の個数と最適化後の補強 パネルの座屈モードの関係を示しており, 図中繸軸は 式(11)における座屈制約条件式の収束值 $g$ である. 図 4(b)より, 最適化後の補強パネルは，ある程度補強材 個数が増加すると全体座屈制約・補強材座屈制約・ キン座屈制約がすべてほぼ 0 となっており, 全体座屈 および2つの局所座屈モードがほぼ同時に生じるよう な座屈特性を有することがわかる。

$3 \cdot 2 \cdot 2$ 荷重比の影霓 次に, 荷重比が $k_{x}: k_{x y}=1: 1$ $\left(N_{x}=N_{x y}=2000 \mathrm{kN} / \mathrm{m}, N_{y}=0\right)$ の組み合わせ荷重条件にお いて補強パネルの最適化を行うとともに, 最適計算結 果に対する荷重比の影響について検討を行う。

最適計算結果を図 5 に示寸. 図 5(a)は, 補強材の個 数と最適化後の補強パネルの重量の関係を示している。 この図より，一軸圧縮の場合（図 4(a)）と同様に補強 材の個数が 15 個程度において最適化後のパネル重量 が収束していることが確認できる．また，図 5(b)は,

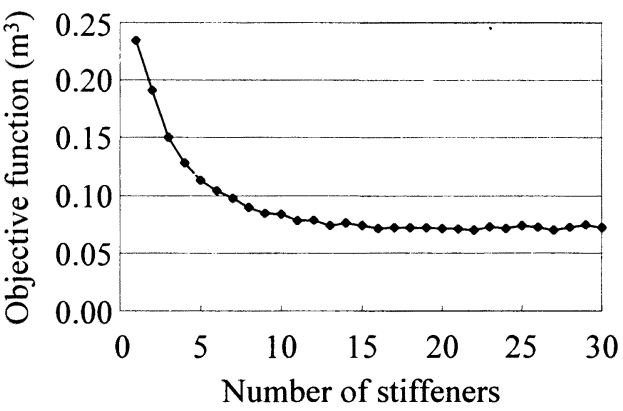

(a) Objective function

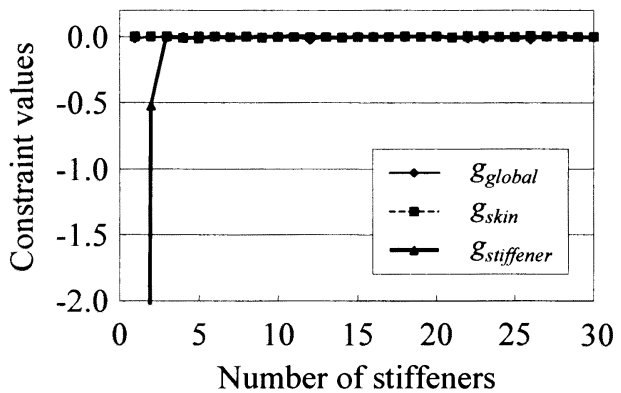

(b) Buckling mode

Fig.5 Optimum results for stiffened panel

$\left(a / b=0.5, k_{x}: k_{x y}=1: 1\right)$

補強材の個数と最適化後の補強パネルの座屈モードの 関係を示している.この図より, 最適化後の補強パネ ルは，一軸圧縮の場合（図 4(b)）と同様に全体座屈お よび2つの局所座屈モードがほぼ同時に生じるような 座屈特性を有することがわかる.

3.3 FEM 解析との比較 次に, 座屈近似式を用 いて得られた最適構造に対し Mindlin の板理論に基づ < FEM 解析を行い，近似式の有効性を検討する. こ こでは, 補強材個数が 10 個の場合について, 近似解と FEM 解析の比較を行う。なお, 荷重比として, $k_{x}: k_{x y}=1: 0\left(\left(N_{x}=2000 \mathrm{kN} / \mathrm{m}, \quad N_{y}=N_{x y}=0\right), \quad k_{x}: k_{x y}=1: 0.5\right.$ $\left(N_{x}=2000 \mathrm{kN} / \mathrm{m}, N_{y}=0, N_{x y}=1000 \mathrm{kN} / \mathrm{m}\right)$ の 2 種類を考える.

近似式を用いた最適設計により得られた形状寸法の 補強パネルの座屈荷重について, FEM 解と近似解の比 較を表 2 に示す．ここで，近似式による座屈荷重につ いては, 3 種類の座屈モードのうち最小の荷重を座屈 荷重とした．この表より，圧縮座屈の場合は両者の座 屈荷重が良く一致していることがわかる，一方，せん 断荷重の割合が大きくなると近似解は FEM 解より高 い值を示す。

また，それぞれの荷重比において FEM 解析により 得られた座屈モード形状を図 6 に示寸. 図 6(a)は荷重 比が 1:0, 図 6(b)は 1:0.5 の場合の座屈モード形状を示 
Table 2 . Buckling load of optimum structures $(a / b=0.5$, number of stiffeners $=10)$

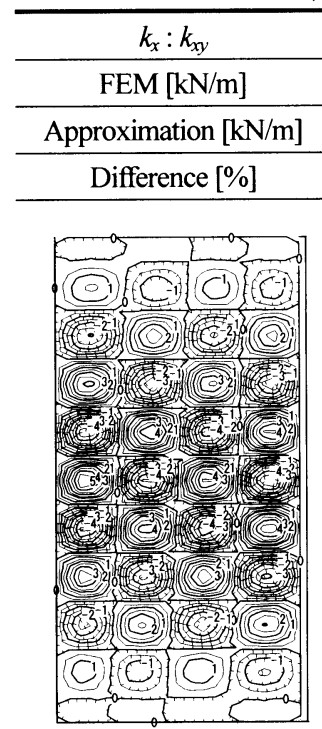

(a) $k_{x}: k_{x y}=1: 0$

\begin{tabular}{cc}
$1: 0$ & $1: 0.5$ \\
\hline 2060 & 1770 \\
\hline 1992 & 1992 \\
\hline 3.3 & 12.5
\end{tabular}

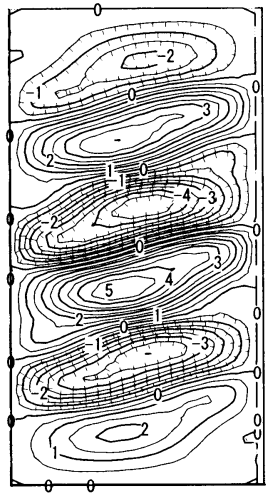

(b) $k_{x}: k_{x y}=1: 0.5$
Fig.6 Buckling mode of stiffened panel (FEM)

す．近似式に基づく最適結果では，すべての座屈モー ドがほぼ同時に生じるような座屈特性を有するが，こ の図より, 荷重比が 1:0 のときは主にスキン座屈を生 じているのに対し，1:0.5の場合は主に全体座屈を生じ ていることがわかる.

\section{4. 箱型瓖構造の最適設計}

\section{$4 \cdot 1$ 箱型翼構造モデと最適化問題の定式化}

4·1·1 箱型翼構造モデル 図 7 に示す箱型翼構造 の上下外板が複合材積層パネルおよび複合材補強パネ ルである場合の最小重量設計を行う。ここで，箱型翼 構造は, 上下外板が面内力を受ける膜要素, 桁ウェブ およびリブがせん断力のみを受けるシェア要素，太い 線で示されている部分が軸力のみを受ける軸要素を用 いて有限要素法によりモデル化する．なお，この構造 には図 8 に示す曲げ荷重およびねじり荷重が同時に作 用する場合を考え，制約条件として最大ひずみ説に基 づくひずみ条件（上下外板および補強材）および座屈 条件を考える.

上下外板が図 1 で示す補強パネルであるとき，膜要 素の面内岡性 $A_{\mathrm{ij}}$ は次式のように近似する.

$$
\begin{aligned}
& A_{11}=\left(A_{11}\right)_{s k i n}+\left(A_{11}\right)_{s t} \frac{h}{d_{s}} \\
& A_{12}=\left(A_{12}\right)_{s k i n}
\end{aligned}
$$

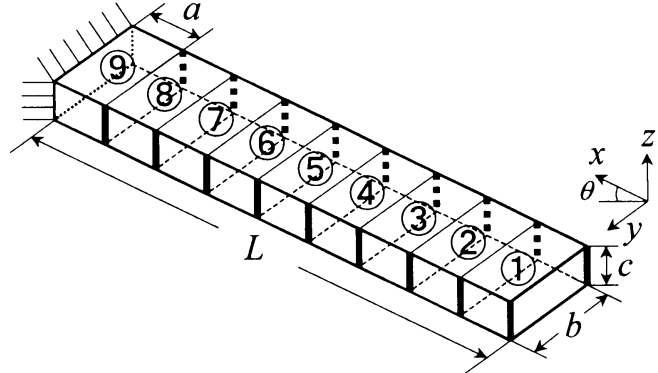

Fig.7 Wing box structures ( $L=15.75 \mathrm{~m}, a=1.75 \mathrm{~m}, b=3.50 \mathrm{~m}, c=0.50 \mathrm{~m})$

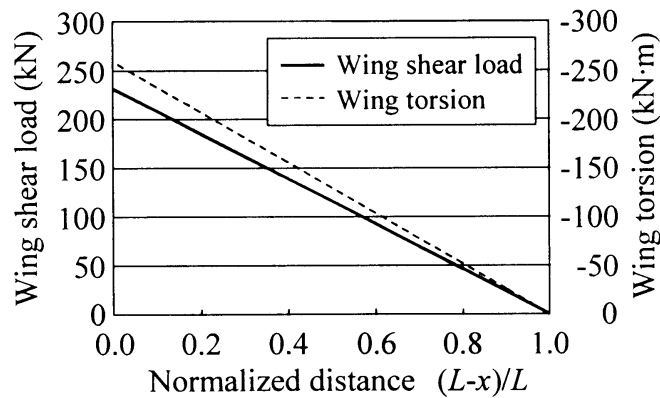

Fig.8 Spanwise load distribution

$$
\begin{aligned}
& A_{22}=\left(A_{22}\right)_{s k i n} \\
& A_{66}=\left(A_{66}\right)_{s k i n}
\end{aligned}
$$

ここで, $\left(A_{\mathrm{ij}}\right)_{s k i n}$ は補強パネルのスキン部分の面内剛性, $\left(A_{\mathrm{ij}}\right)_{s t}$ は補強材部分の面内岡性である.

4.1.2 最適化問題の定式化 上下外板が図 1 で示 すブレード型補強パネルである場合の最小重量設計問 題の定式化を行う。スキンおよび補強材の積層構成は それぞれ $[ \pm 45 / \mp 45 / 0 / 90]_{s} ，[ \pm 45 / \mp 45 / 0]_{s}$ とし， CFRPの材料定数を表 1 に示す.ここで, $\varepsilon_{l c r}, \varepsilon_{L c r} \varepsilon_{T c r} \varepsilon_{T c m}$ $\gamma_{L T C r}$ はそれぞれ䋊維方向の引張り許容ひずみ, 圧縮許 容ひずみ, 䋊維に垂直方向の引張り許容ひずみ, 圧縮 許容ひずみ, せん断許容ひずみである. なお, 対象と する補強パネルにおいて補強材の個数 $N$ は 15 とした. このとき, 最適化問題は次式のように定式化される.

$$
\begin{array}{ll}
\text { subject to } & g_{\varepsilon}=\frac{\varepsilon}{\varepsilon_{c r}}-1 \leq 0 \\
& g_{\text {global }}=1-\lambda_{\text {global }} \leq 0 \\
& g_{\text {skin }}=1-\lambda_{\text {skin }} \leq 0 \\
& g_{\text {stiffner }}=1-\lambda_{s t} \leq 0
\end{array}
$$$$
\text { minimize } W=2 \sum_{i=1}^{9}\left\{\left(\left(t_{0}^{\text {skin }}\right)_{i}+\left(t_{ \pm 45}^{\text {skin }}\right)_{i}+\left(t_{90}^{\text {skin }}\right)_{i}\right) b\right.
$$$$
\left.+\left(\left(t_{0}^{s t}\right)_{i}+\left(t_{ \pm 45}^{s t}\right)_{i}\right) N h_{i}\right\} a
$$ 
Table 3 Optimization cases investigated

\begin{tabular}{|c|c|c|c|}
\hline & & Upper/lower panel & Constraints \\
\hline & Case A & \multirow{2}{*}{ Laminated panel } & Strain \\
\hline & Case B & & \multirow{3}{*}{ Strain and Buckling } \\
\hline & Case C & \multirow{2}{*}{ Stiffened panel } & \\
\hline$*$ & Case D & & \\
\hline
\end{tabular}

*: Applied load is 15 times of the other cases

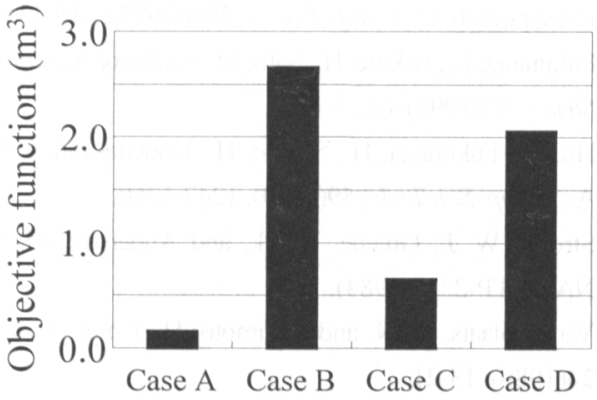

Fig.9 Comparison of objective function values

$$
t_{i}^{L} \leq t_{i} \leq t_{i}^{U}, \quad h_{i}^{L} \leq h_{i} \leq h_{i}^{U}
$$

design variables: $\left(t_{0}^{s k i m}\right)_{i},\left(t_{ \pm 45}{ }^{s k i m}\right)_{i},\left(t_{90}{ }^{s k i n}\right)_{i},\left(t_{0}^{s t}\right)_{i},\left(t_{ \pm 45^{s t}}\right)_{i}, h_{i}$ ここで， $g_{\varepsilon}$ はひずみ条件である，また，座屈条件に含 まれる $\lambda_{\text {global }}, \lambda_{\text {skim }}, \lambda_{s t}$ は座屈近似式より求める.さらに, $t_{i}^{L}, t_{i}^{U}, h_{i}^{L}, h_{i}^{U}$ はそれぞれ層厚と補強材高さの下限值と 上限值であり, すべての要素において $t_{i}^{L}=1.00 \times 10^{-5} \mathrm{~m}$, $t_{i}^{U}=0.100 \mathrm{~m}, h_{i}^{L}=1.00 \times 10^{-2} \mathrm{~m}, h_{i}^{U}=1.00 \mathrm{~m}$ を用いた. 最適化 手法として, ADS プログラムにおける許容方向法（1 次元探索は黄金分割法) を適用した。

また，上下外板が積層パネルである場合についても， 式(13)と同様に定式化される(15).

$4 \cdot 2$ 計算結果および考察＼cjkstart本研究では, 表 3 に 示寸 4 つのケースについて最適化計算を行う. 目的関 数の収束值 $\mathrm{W}$ を図 9 に示す. ケース $\mathrm{A}, \mathrm{B}$ の值の比較 より, 積層パネルで座屈を考慮すると構造重量が大幅 に増加していることがわかる. そこで, 積層パネルの 代わりに補強パネルを用いた結果をケース $\mathrm{C}$ に示す. ケース B,C の值の比較より, 補強パネルでは積層パネ ルの場合に比べて構造重量が $70 \%$ 以上減少しておう, 補強パネルが座屈に対し非常に有効であることが確認 できる、この最適化された補強パネルにおけるスキン と補強材の積層構成および補強材高さを図 10 に示寸. 翼根に近づくにつれ，スキン・補強材の層厚および補 強材高さのす心゙てが増加していることがわかる. また， 補強材部分では $0^{\circ}$ 層が，スキン部分では $445^{\circ}$ 層が増加 することにより, 而座屈能力に優れた積層構成となっ

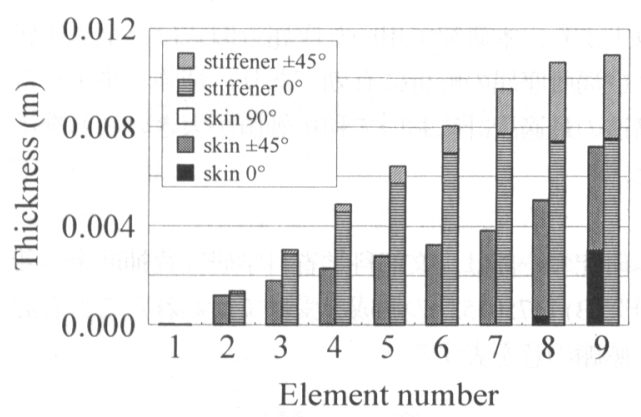

(a) Layer thickness distribution

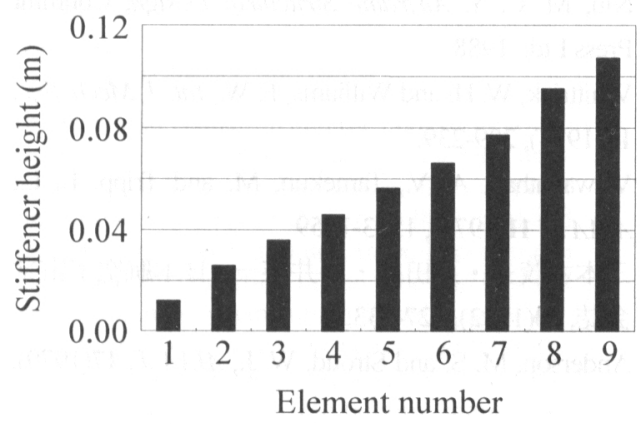

(b) Stiffener height distribution

Fig.10 Optimum results for case C

ている.

ケース Cの制約条件では，ひずみ条件に比べ座屈条 件が非常にクリティカルになる．そこで翼構造に作用 する荷重を 15 倍にした結果をケース D に示す. 荷重 の増大により，ひずみ条件と座屈条件がほぼ同程度に クリティカルになり, 強度破壊と座屈がほぼ同時に生 じることが確認された ${ }^{(15)}$. また, 荷重の増大により, 補強パネルの重量も大幅に増加している.

\section{5. 結言}

本研究では, ブレード型補強パネルの全体座屈およ び局所座屈の解析において古典積層理論に基づく近似 式を適用し，座屈近似式を用いて補強パネルおよび補 強パネル翼構造の最適設計を行った。初めに，ブレー ド型補強パネルの全体座屈および局所座屈の解析にお いて古典積層理論に基づく近似式が有効であることを FEM 解析と比較することにより示した. 次に, 座屈近 似式を用いて補強パネルの形状寸法最適化を行い, 補 強材個数および組み合わせ荷重条件が最適形状寸法に およぼす影響を検討するとともにその有効性を示した。 また，箱型翼構造の上下外板に補強パネルを用いるこ とにより座屈特性を大幅に改善できることから, 構造 重量が大幅に削減されることを確認した。 
以上より, 本研究で用いた座屈近似式は, 全体座屈 および局所座屈の解析に有効であり, 補強パネルを含 む構造の最適設計において利用価值が大きいことを示 した.

本研究の一部は, 文部科学省科学研究費補助金 (若 手研究(B) 14750153)の助成を受けて行われたことを記 し, 感謝の意を表する.

\section{文献}

(1) Niu, M. C. Y, Airframe Structural Design, Conmilit Press Ltd., 1988.

(2) Whittrick, W. H. and Williams, F. W., Int. J. Mech. Sci., 16(1974), 209-239.

(3) Viswanathan, A. V., Tamekun, M. and Tripp, L. L., ALAA J., 11(1973), 1553-1559

(4) 三本木茂夫 - 戸田勧 - 中井暎一, 日本航空宇宙学 会誌, 30(1982), 127-133.

(5) Anderson, M. S. and Stroud, W. J., AIAA J., 17(1979),
892-897.

(6) Bushnell, D., Comp. Struct., 25(1987), 469-605.

(7) Schmit, L. A. and Mehrinfar, M., ALAA J., 20(1982), 138-147.

(8) Nagendra, S., Jestin, D., Gürdal, Z., Haftka, R. T. and Watson, L.T., Comp. Struct., 58(1996), 543-555.

(9) Harrison, P. N., Le Riche, R. and Haftka, R. T., AIAA 95-1163-CP(1995), 58-68.

(10) Kassapoglou, C., Comp. Part A, 28A(1997), 419-435.

(11) Fukunaga, H., Sekine, H., Sato, M., and lino, A., Comp. Struct., 57(1995), 643-649.

(12) Hu, N., Fukunaga, H., Sekine, H., Kouchakzadeh, M. A., Comp. Sci. Tech, 59(1999), 1247-1260.

(13) Stroud, W. J., Greene, W. H., and Anderson, M. S., NASA TP-2215(1984).

(14) Vanderplaats, G. N. and Sugimoto, H., Comp. Struct., 24(1986), 13-21.

(15) 加藤洋子, 東北大学修士学位論文, (2002-2). 